\title{
Inductively Coupled Plasma Atomic Emission Spectrometric Analysis of Cobalt-base Superalloys*
}

\author{
A. Gómez Coedo, M. T. Dorado López and A. Vindel Maeso \\ Centro Nacional de Investigaciones Metalurgicas. Av. Gregorio del Amo 8, 28040 Madrid, Spain
}

\begin{abstract}
This paper describes the procedure developed for the accurate analysis by ICP-AES of Co-base superalloys, using yttrium as an internal standard. The chemical composition of these materials makes the development of spectroscopic analytical methods difficult due to the presence of major elements that exhibit intense and complex ICP emission spectra. A quantitative sample dissolution procedure and careful selection of the analytical lines used was carried out. The elements investigated were $\mathrm{Co}, \mathrm{Cr}, \mathrm{Ni}, \mathrm{W}, \mathrm{Fe}, \mathrm{Ta}, \mathrm{Nb}, \mathrm{Al}, \mathrm{Mo}$ and $\mathrm{Mn}$. Synthetic solutions were used for calibration, and standard samples were analysed to demonstrate the precision and accuracy of the developed method.
\end{abstract}

Keywords: Cobalt-base superalloys; inductively coupled plasma atomic emission spectrometry

Cobalt solid-solution alloys can be sub-divided in three simple groups on the basis of use: $(a)$ alloys for use primarily at temperatures from 650 to $1150^{\circ} \mathrm{C} ;(b)$ fastener alloys for use to about $650{ }^{\circ} \mathrm{C}$; and $(c)$ wear resistant alloys. ${ }^{i-3}$

The range of concentrations of elements present in Co-base superalloys are as follows: $\mathrm{Co}, 48-67 ; \mathrm{Cr}, 19-32 ; \mathrm{Ni}, 0.5-24$; W, 0.5-16; Fe, 0.5-2.0; Ta, 0.1-10; Nb 0.1-2; Al, 0.1-5; Mo, $0.1-2 ;$ and $\mathrm{Mn}, 0.1-2 \%$.

The most widely used method for analysing Co-base superalloys involves laborious gravimetric and titrimetric procedures. However, inductively coupled plasma atomic emission spectrometry (ICP-AES) is now a well established technique for the analysis of metallurgical samples. The objective of the present study was to establish a single and accurate ICP analytical method, using internal standardisation, that was suitable for the determination of the fundamental components in Co-base superalloys..$^{4,5}$

The major elements normally present in these materials exhibit intense and complex ICP atomic emission spectra. At high concentrations, the more intense lines of an element may emit significant radiation several nanometres either side of the selected wavelength, increasing the likelihood of interferences from spectral overlap, and selection of the correct analytical lines is therefore difficult.

In order to select the wavelengths to be used, spectral scans of solutions containing, approximately, the background equivalent concentration (BEC) of the element being considered and the maximum expected concentrations of all the other possible elements, were taken. The most prominent line of each element was investigated first, and if an interference was found, then the next most prominent line was checked, until one was found which had no significant interference.

The precision and accuracy of the developed method were checked, first with synthetic samples prepared with the appropriate proportions of the pure metals, and finally with three MBH standard samples (MBH Reference Materials, Barnet, Hertfordshire, UK).

\section{Experimental}

\section{Instrumentation}

A Jobin-Yvon, JY 38 P, ICP sequential emission spectrometer with a scanning monochromator (0.60-m JY HRS 2), mounted at $90^{\circ}$ to the JY $38 \mathrm{P}$ optical path was used.

\footnotetext{
* Presented at the 1987 Winter Conference on Plasma and Laser Spectrochemistry, Lyon, France, 12th-16th January, 1987.
}

\section{Specifications}

Spectrometer, JY 38 P. Focal length, 1-m, Czerny - Turner; grating, holographic 2.400 grooves per $\mathrm{mm}$; spectral range, $175-700 \mathrm{~nm}$; dispersion, $4 \mathrm{~A}$ per $\mathrm{mm}$ at $200 \mathrm{~nm}$; and accuracy, $0.5 \mathrm{~A}$.

Generator. Plasma Therm, $27.12 \mathrm{MHz}$, maximum power rating $1.5 \mathrm{~kW}$.

Torch. Monoblock Scott - Fassel, modified with a cylindrical injector and argon sheath gas flow (Fig. 1).

Nebuliser. Jobin-Yvon, with Pt - Ir capillary and PTFE nozzle.

Instrument control and data processing. Apple IIe computer with associated EPSON RX $80 F / X$ printer.

\section{Analytical operating conditions}

The conditions used were as follows: power, $1.2 \mathrm{~kW}$ forward; outer gas flow-rate, $151 \mathrm{~min}^{-1}$; aerosol carrier gas, humidified, $0.551 \mathrm{~min}^{-1}$; argon sheath gas flow-rate, $0.11 \mathrm{~min}^{-1}$; sample delivery rate, $1.6 \mathrm{ml} \mathrm{min}^{-1}$; and observation height, 14-16 mm. Using these gas rates and the modified torch employed, RSDs of $\leqslant 0.4 \%$ were obtained.

\section{Sample Dissolution}

Dissolve $0.5 \mathrm{~g}$ of sample in a PTFE beaker with $50 \mathrm{ml}$ of aqua regia containing $2 \mathrm{ml}$ of hydrofluoric acid; add $25 \mathrm{ml}$ of sulphuric acid $(33 \% \mathrm{~V} / \mathrm{V})$ and $25 \mathrm{ml}$ of phosphoric acid $(33 \%$ $V / V)$ and evaporate to fumes; dilute to $c a .40 \mathrm{ml}$ with hydrochloric acid $(10 \% \mathrm{~V} / \mathrm{V})$. If undissolved matter remains,

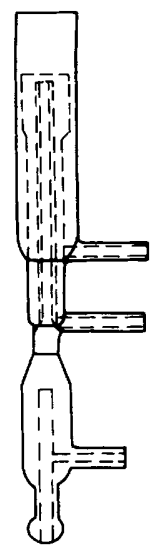

Fig. 1. Monoblock Scott - Fassel torch, modified with cylindrical injector and argon sheath gas flow 

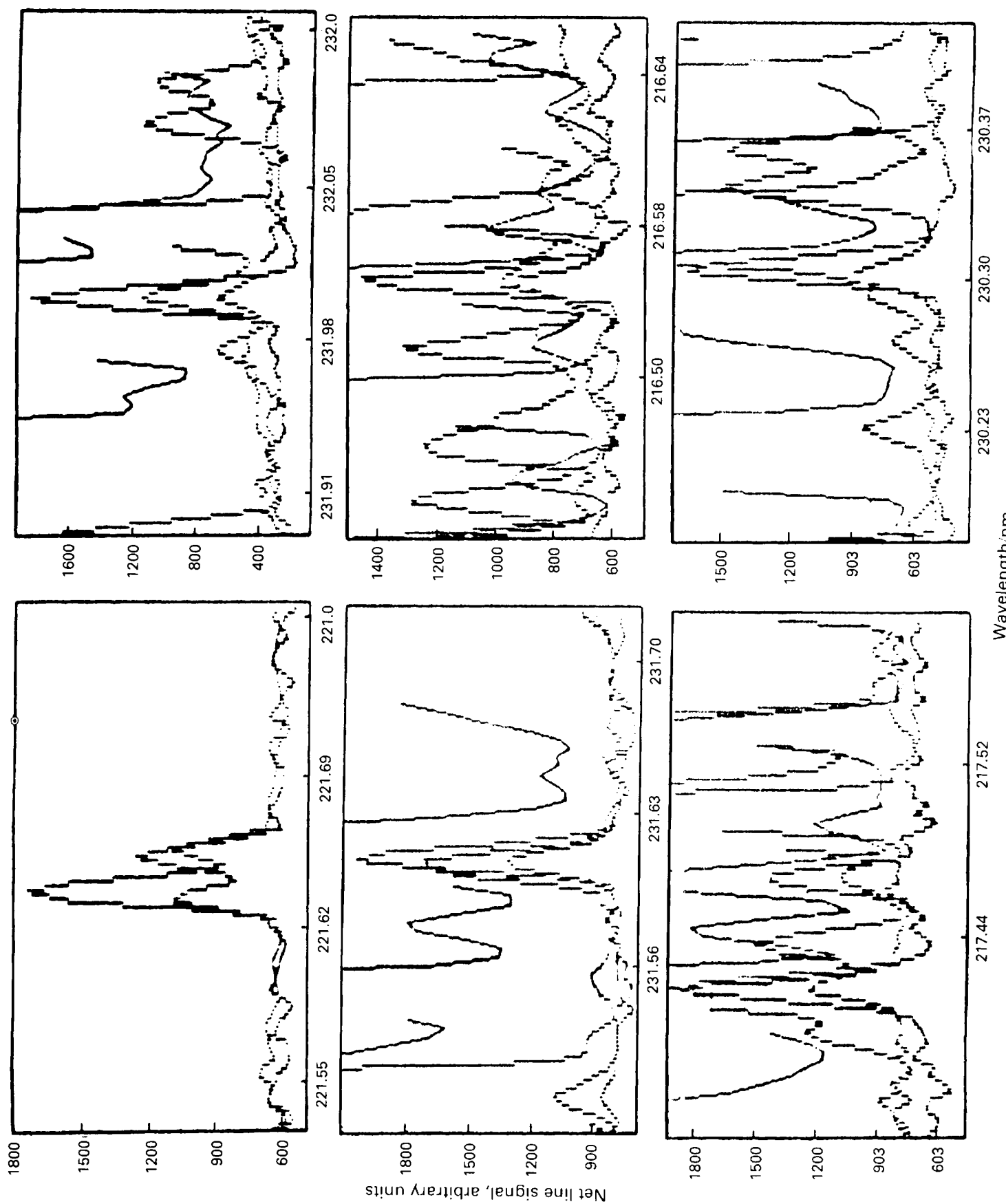

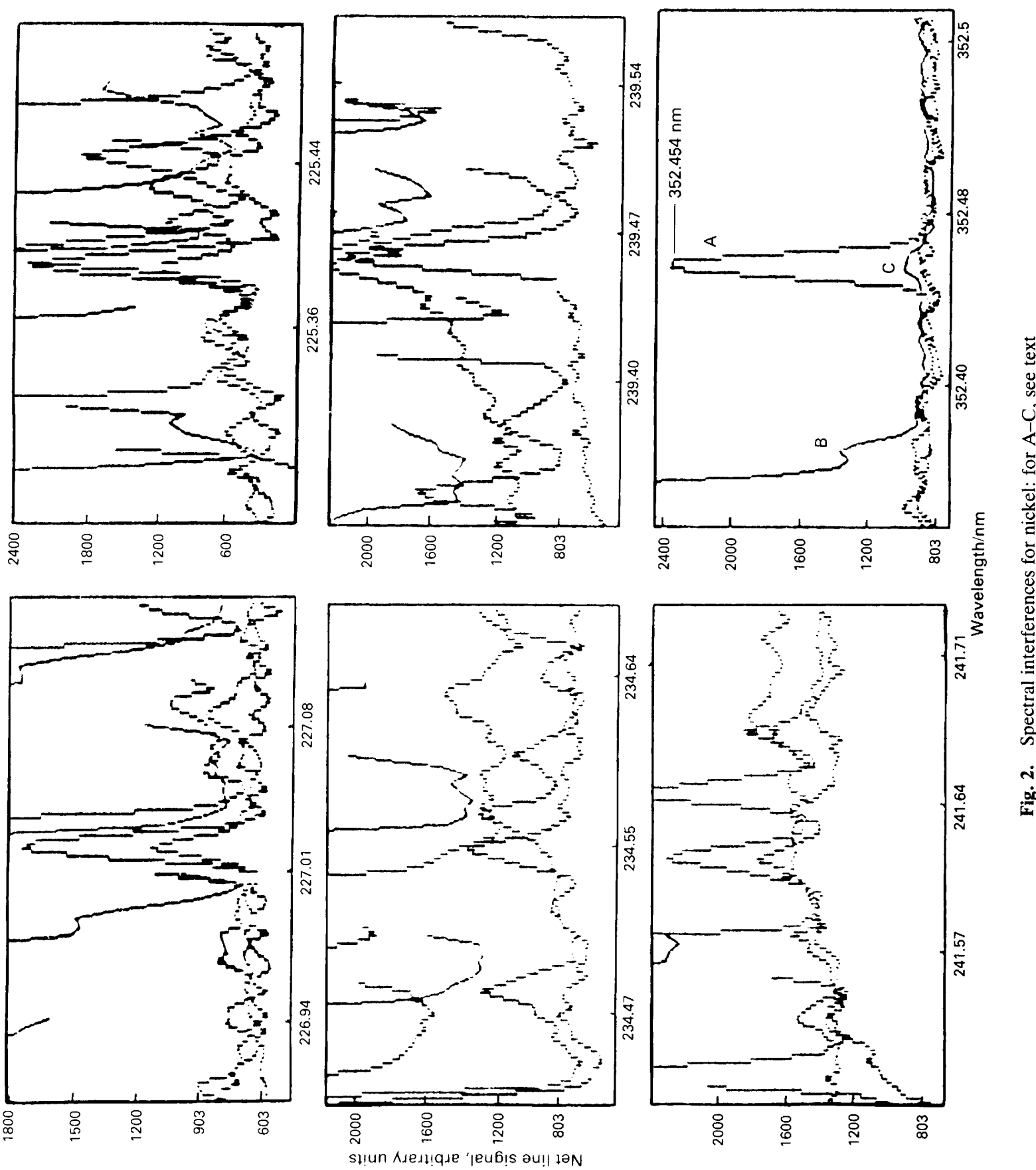
View Article Online

$\sum^{\dot{2}} 632$

JOURNAL OF ANALYTICAL ATOMIC SPECTROMETRY, SEPTEMBER 1987, VOL. 2
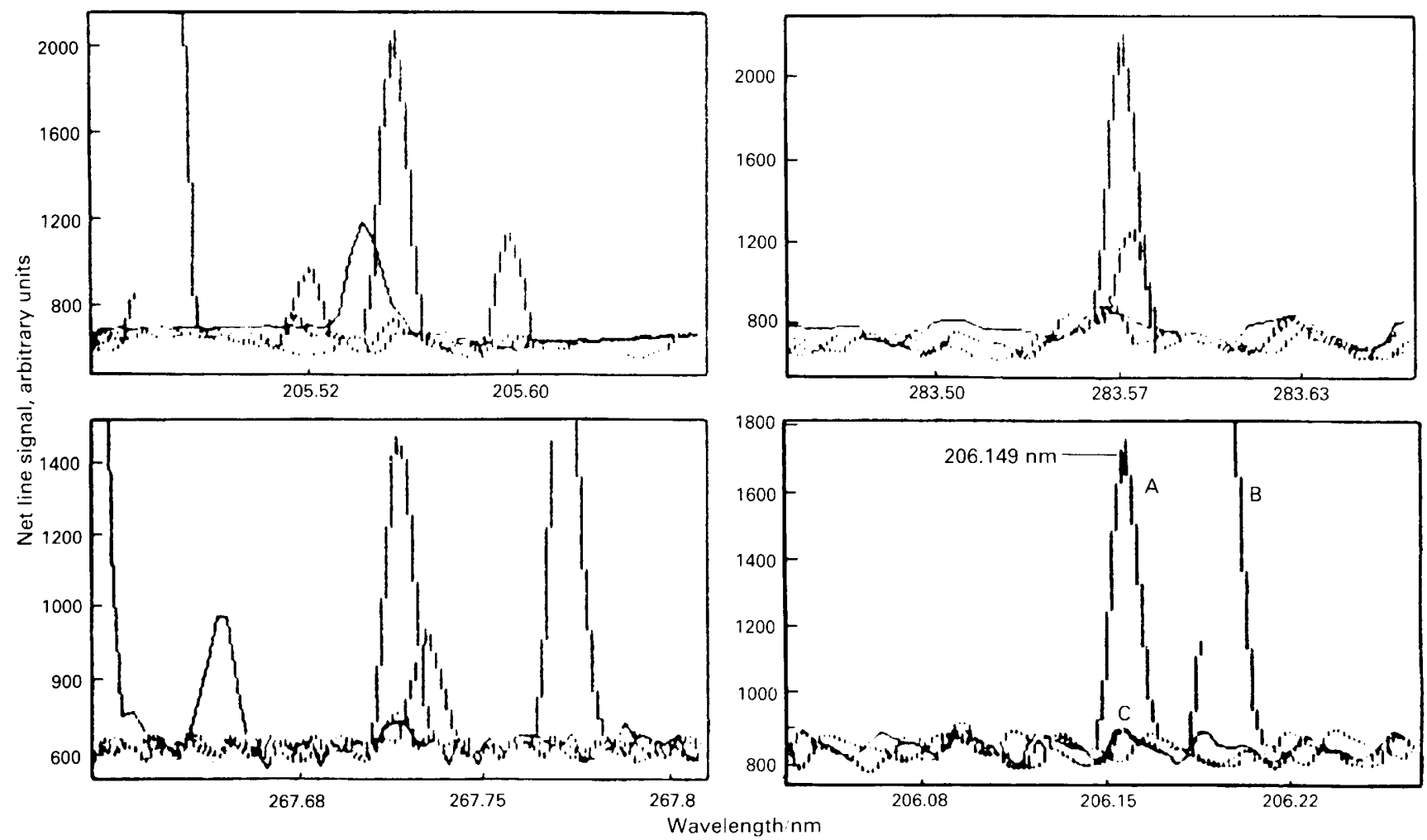

Fig. 3. Spectral interferences for chromium

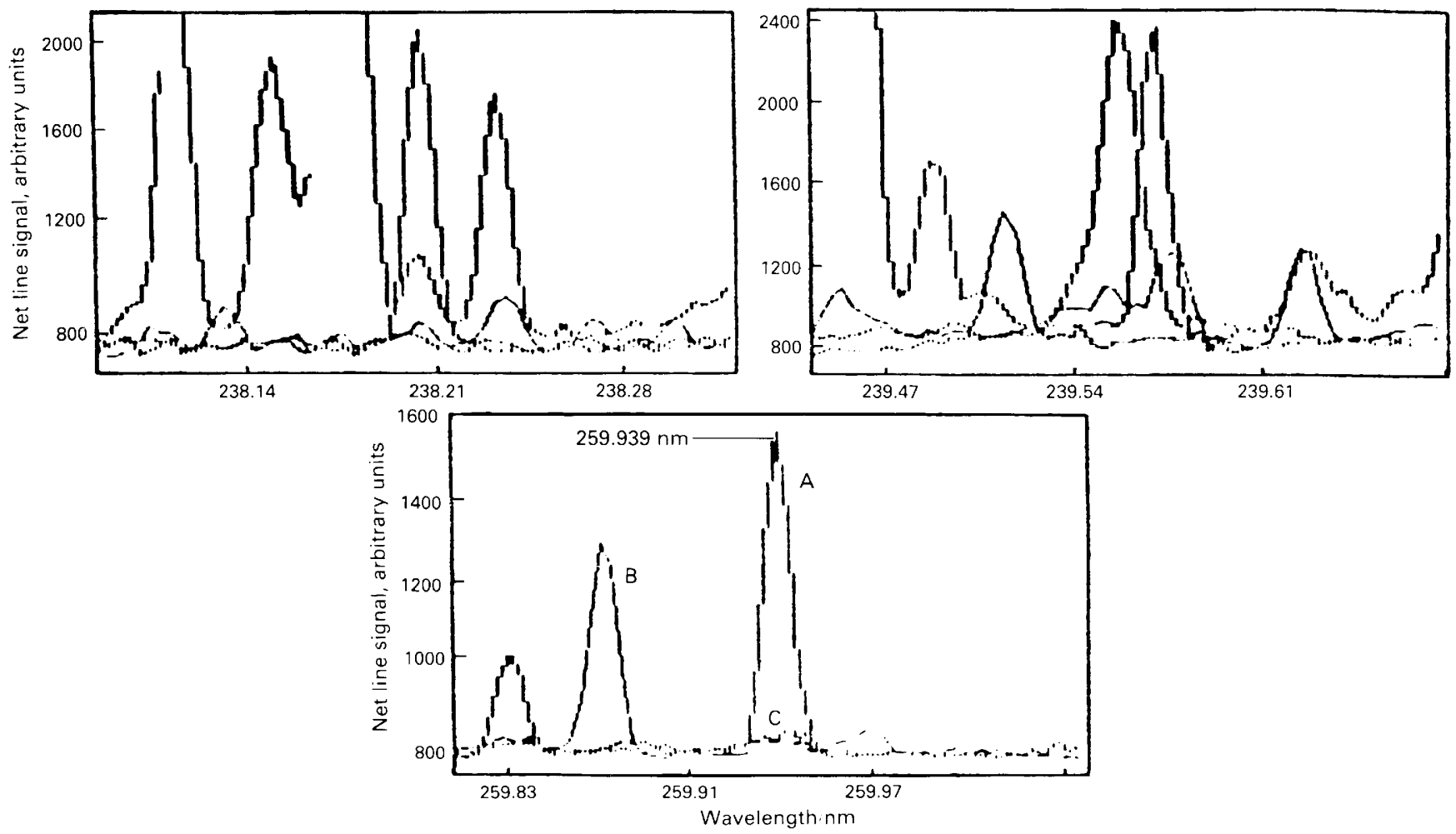

Fig. 4. Spectral interferences for iron 

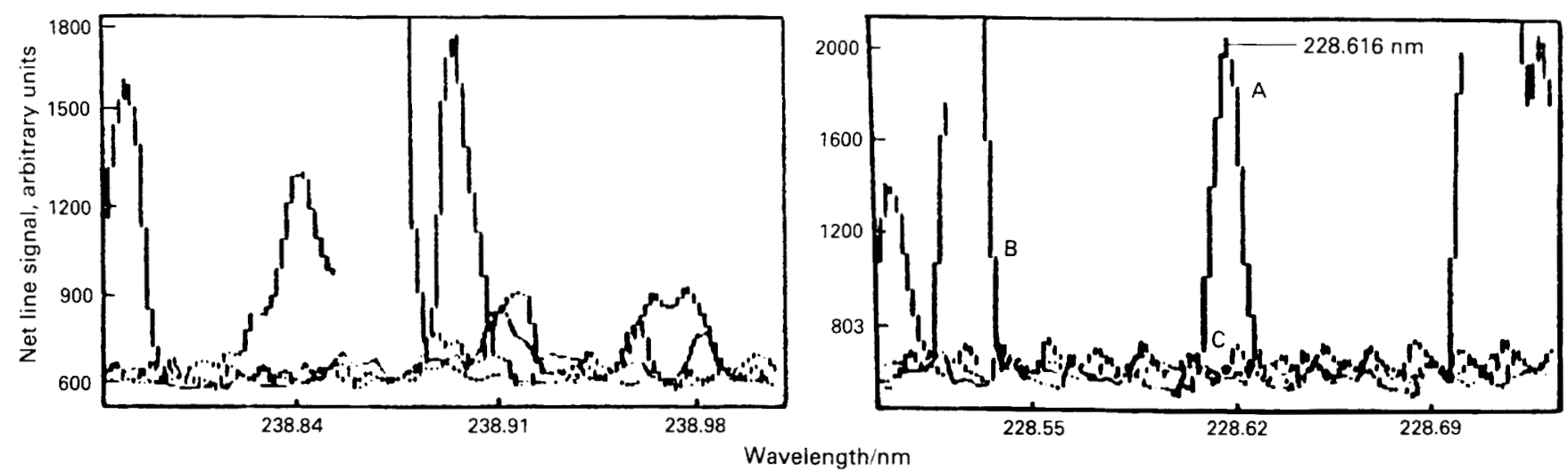

Fig. 5. Spectral interferences for cobalt
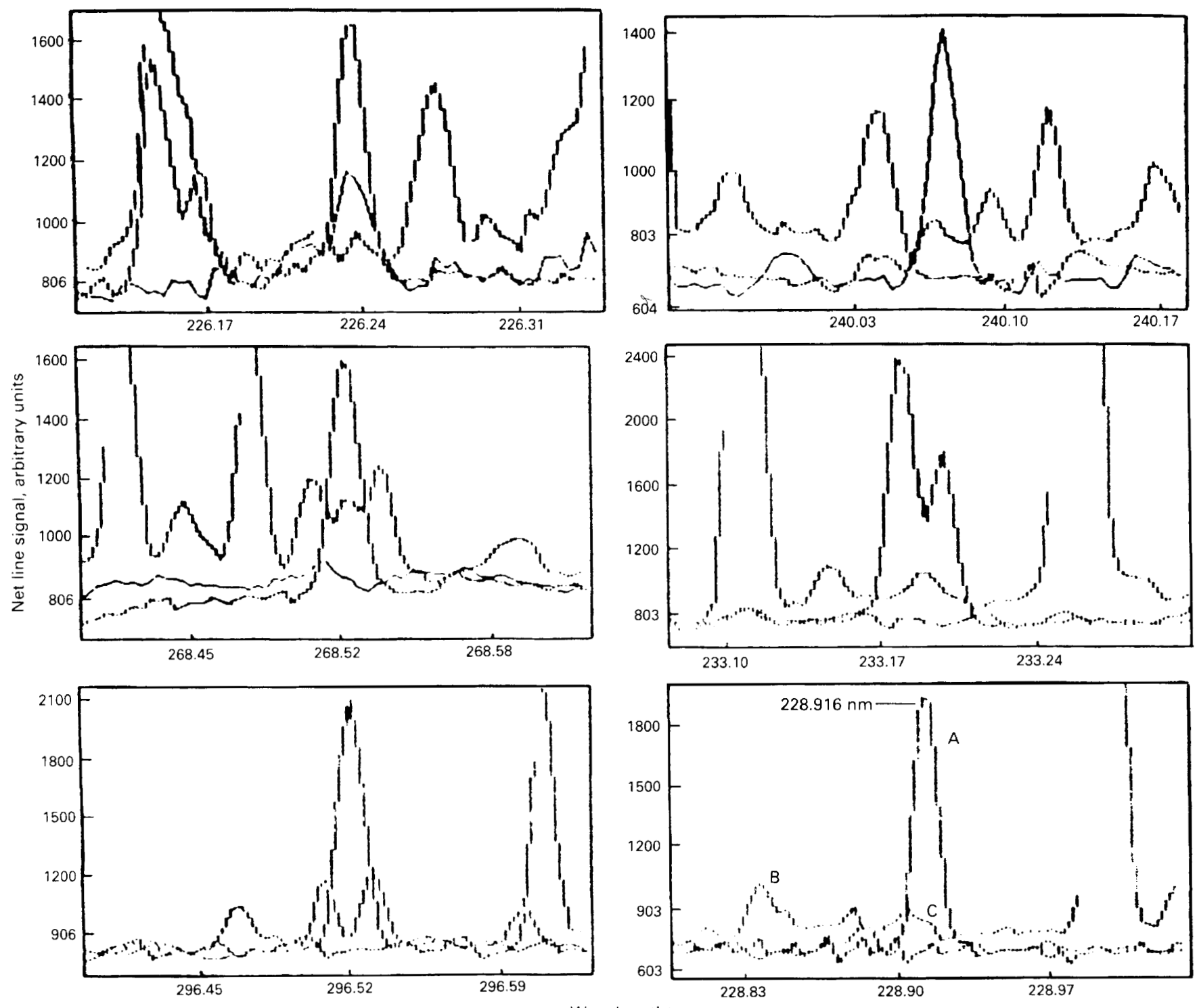

Fig. 6. Spectral interferences for tantalum 


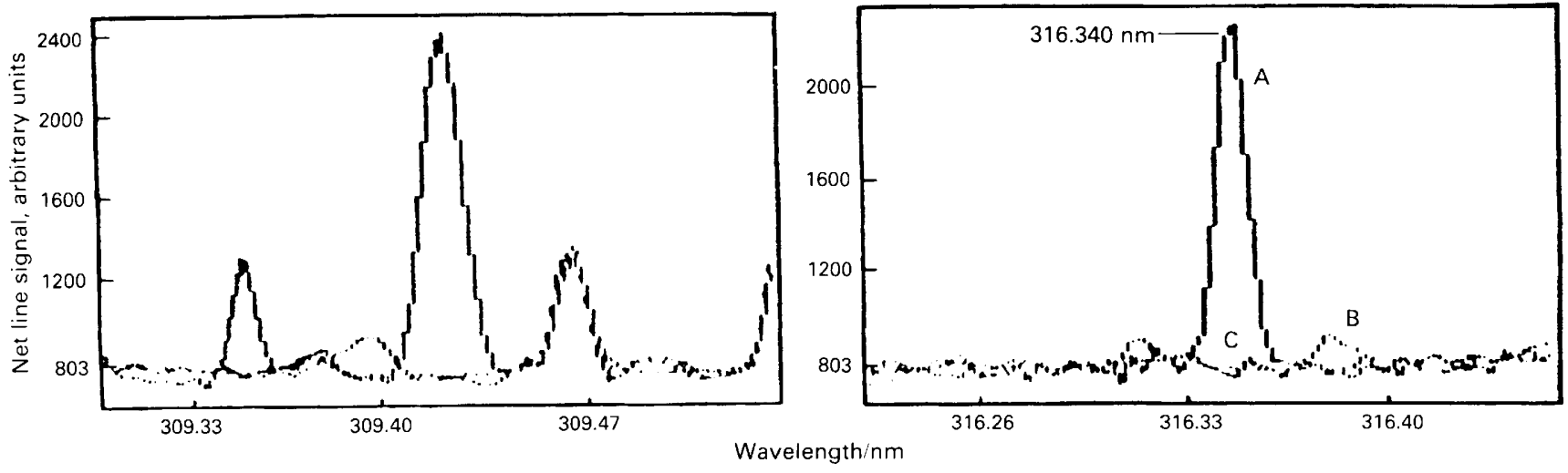

Fig. 7. Spectral interferences for niobium
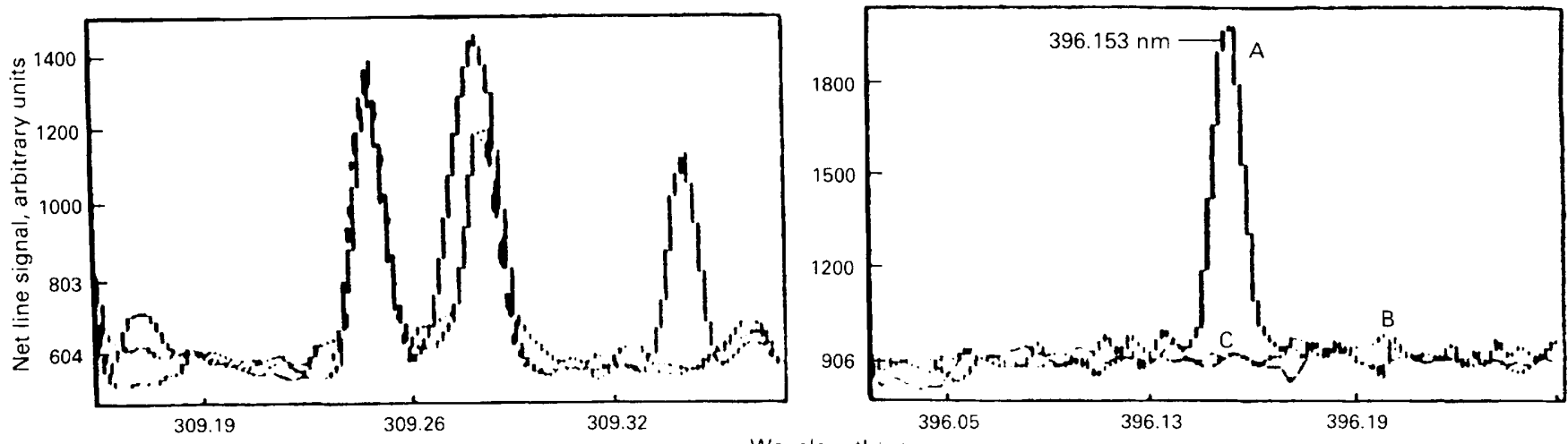

Fig. 8. Spectral interferences for aluminium

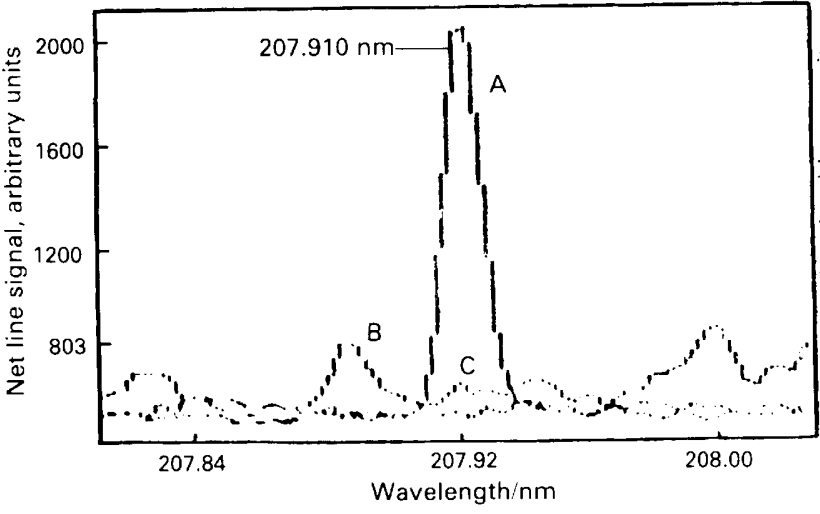

Fig. 9. Spectral interferences for tungsten

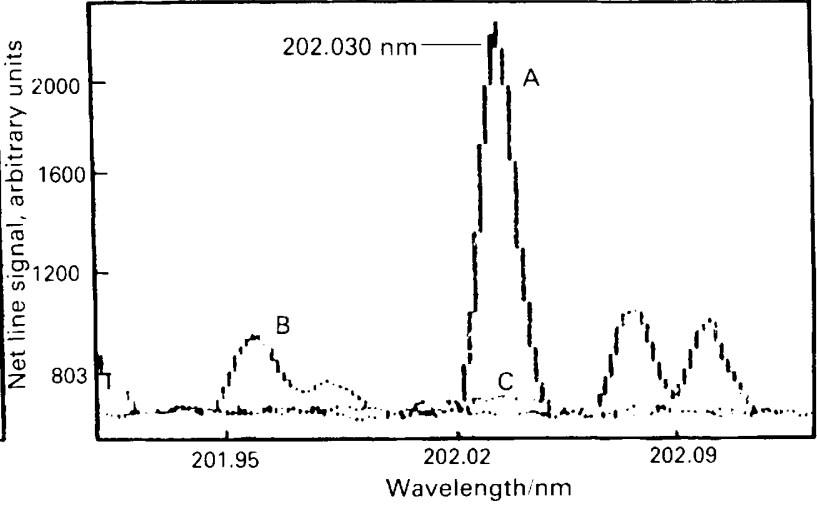

Fig. 10. Spectral interferences for molybdenum filter the solution, transfer the filter-paper into a platinum crucible and dry. Ignite the filter-paper, then heat at about $1000{ }^{\circ} \mathrm{C}$ for about $15 \mathrm{~min}$. Allow to cool, then add $2 \mathrm{ml}$ of sulphuric acid, $5 \mathrm{ml}$ of hydrofluoric acid and, dropwise, about $1 \mathrm{ml}$ of nitric acid to the crucible. Heat gently then, when the acids have evaporated, heat again at $1000{ }^{\circ} \mathrm{C}$ for a few minutes and fuse the residue with $0.5 \mathrm{~g}$ of sodium carbonate. Extract the cooled melt into the main acid solution and dilute to $500 \mathrm{ml}$ with hydrochloric acid $(10 \% V / V) .6,7$

The assay solution was prepared by adding 50 p.p.m. of yttrium to $25 \mathrm{ml}$ of the main acid sample solution and diluting to $100 \mathrm{ml}$ with $10 \% \mathrm{HCl}(\mathrm{V} / \mathrm{V})$. A solution of yttrium was prepared by dissolving $1.25 \mathrm{~g}$ of $\mathrm{Y}_{2} \mathrm{O}_{3}$ in $100 \mathrm{ml}$ of nitric acid $(1+1)$ and diluting to $1000 \mathrm{ml}$ with water; $5 \mathrm{ml}$ of this solution contained 50 p.p.m. of yttrium. The assay solution therefore contains $0.025 \mathrm{~g}$ of sample plus $5 \mu \mathrm{g}$ of yttrium per $100 \mathrm{ml}$.

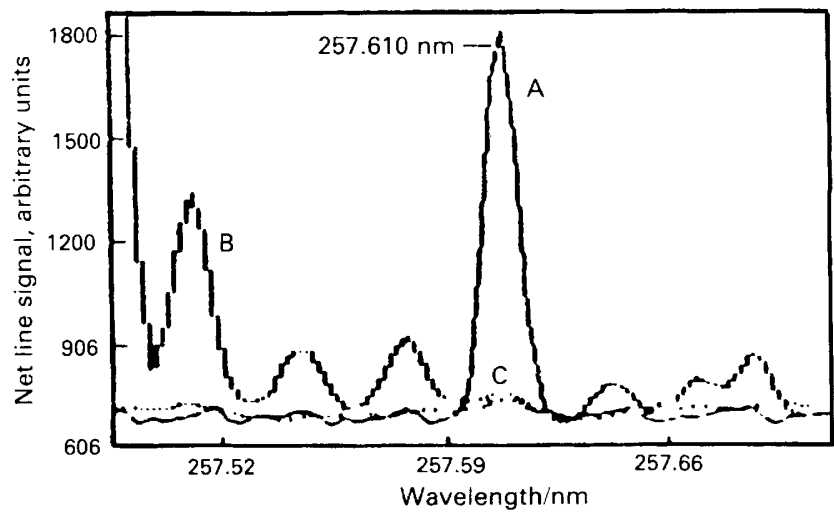

Fig. 11. Spectral interferences for manganese 
Table 1. Lines examined for each element

\begin{tabular}{|c|c|c|c|c|c|}
\hline & Element & $\mathrm{N} / \mathrm{nm}$ & & Element & $\lambda / \mathrm{nm}$ \\
\hline Co & . $\quad \ldots$ & $\begin{array}{r}238.892 \\
228.616\end{array}$ & $\mathrm{Fe}$ & . $\quad \ldots$ & $\begin{array}{r}238.204 \\
239.562\end{array}$ \\
\hline \multirow[t]{2}{*}{$\mathrm{Ta}$} & . & .. 226.230 & & & 259.940 \\
\hline & & $\begin{array}{l}240.063 \\
268.517 \\
233.193 \\
296.516 \\
228.916\end{array}$ & $\mathrm{Ni}$ & $\cdots$ & $\begin{array}{r}221.647 \\
232.003 \\
231.604 \\
216.556 \\
217.467\end{array}$ \\
\hline $\mathrm{Al}$ & . & $\begin{array}{r}309.271 \\
396.152\end{array}$ & & & $\begin{array}{l}230.300 \\
227.021\end{array}$ \\
\hline $\mathrm{Cr}$ & . & $\begin{array}{r}205.552 \\
267.716 \\
283.546 \\
206.149\end{array}$ & & & $\begin{array}{l}225.580 \\
234.554 \\
239.452 \\
241.614 \\
352.454\end{array}$ \\
\hline \multirow{3}{*}{$\begin{array}{l}\text { Mo } \\
\text { W }\end{array}$} & $\cdots$ & . . 202.030 & $\mathrm{Nb}$ & $\ldots$ & . . 309.418 \\
\hline & . & . 207.911 & & & 316.340 \\
\hline & & & $\mathrm{Mn}$ & . & . 257.616 \\
\hline
\end{tabular}

Table 2. Certified and ICP-AES results for $\mathrm{MBH}$ samples

\begin{tabular}{|c|c|c|c|c|c|c|}
\hline \multicolumn{3}{|c|}{ Element } & \multirow{2}{*}{$\begin{array}{c}\text { Sample } \\
14937 \mathrm{H} \\
\mathrm{X} 405 \mathrm{~B} \\
12671 \mathrm{~F}\end{array}$} & \multicolumn{2}{|r|}{$\begin{array}{c}\text { Found } \\
\text { value, \% } \\
(\bar{X} \pm t)^{*}\end{array}$} & $\mathrm{RSD},+\%$ \\
\hline $\mathrm{Co}$ & . & . & & $\begin{array}{l}\text { Remainder } \ddagger \\
\text { Remainder } \ddagger \\
\text { Remainder } \ddagger\end{array}$ & $\begin{array}{l}59.84 \pm 0.25 \\
54.95 \pm 0.20 \\
63.37 \pm 0.25\end{array}$ & $\begin{array}{l}0.20 \\
0.18 \\
0.21\end{array}$ \\
\hline $\mathrm{Cr}$ & . & $\ldots$ & $\begin{array}{c}14937 \mathrm{H} \\
\mathrm{X} 405 \mathrm{~B} \\
12671 \mathrm{~F}\end{array}$ & $\begin{array}{l}26.48 \\
24.24 \\
20.48\end{array}$ & $\begin{array}{l}26.60 \pm 0.10 \\
24.17 \pm 0.10 \\
20.57 \pm 0.10\end{array}$ & $\begin{array}{l}0.17 \\
0.18 \\
0.20\end{array}$ \\
\hline $\mathrm{Ni}$ & . & $\cdots$ & $\begin{array}{l}14937 \mathrm{H} \\
\mathrm{X} 405 \mathrm{~B} \\
12671 \mathrm{~F}\end{array}$ & $\begin{array}{r}2.43 \\
10.80 \\
0.77\end{array}$ & $\begin{array}{r}2.45 \pm 0.015 \\
10.76 \pm 0.060 \\
0.76 \pm 0.005\end{array}$ & $\begin{array}{l}0.28 \\
0.22 \\
0.20\end{array}$ \\
\hline W & . & $\cdots$ & $\begin{array}{l}14937 \mathrm{H} \\
\mathrm{X} 405 \mathrm{~B} \\
12671 \mathrm{~F}\end{array}$ & $\begin{array}{r}2.52 \\
7.62 \\
10.88\end{array}$ & $\begin{array}{r}2.45 \pm 0.012 \\
7.56 \pm 0.040 \\
10.87 \pm 0.062\end{array}$ & $\begin{array}{l}0.24 \\
0.28 \\
0.18\end{array}$ \\
\hline $\mathrm{Fe}$ & $\begin{array}{l}\cdots \\
\cdots\end{array}$ & $\begin{array}{l}\cdots \\
\ldots\end{array}$ & $\begin{array}{c}14937 \mathrm{H} \\
\mathrm{X} 405 \mathrm{~B} \\
12671 \mathrm{~F} \\
12671 \mathrm{~F}\end{array}$ & $\begin{array}{c}0.77 \\
1.19 \\
1.08 \\
(0.10)\end{array}$ & $\begin{array}{l}0.75 \pm 0.006 \\
1.25 \pm 0.010 \\
1.00 \pm 0.010 \\
0.13 \pm 0.010\end{array}$ & $\begin{array}{l}0.26 \\
0.19 \\
0.12 \\
0.38\end{array}$ \\
\hline $\mathrm{Nb}$ & . & . & $12671 \mathrm{~F}$ & 2.27 & $2.30 \pm 0.040$ & 0.34 \\
\hline $\mathrm{Al}$ & . & $\ldots$ & $14937 \mathrm{H}$ & 1.17 & $1.22 \pm 0.035$ & 0.40 \\
\hline Mo & . & . & $14937 \mathrm{H}$ & 5.90 & $6.00 \pm 0.12$ & 0.33 \\
\hline $\mathrm{Mn}$ & . & . & $\begin{array}{l}14937 \mathrm{H} \\
12671 \mathrm{~F}\end{array}$ & $\begin{array}{l}0.32 \\
0.61\end{array}$ & $\begin{array}{l}0.35 \pm 0.024 \\
0.60 \pm 0.025\end{array}$ & $\begin{array}{l}0.31 \\
0.24\end{array}$ \\
\hline & $\begin{array}{l}\bar{X}, \mathrm{M} \\
\text { tolera } \\
\text { RSD } \\
\text { ame } \\
\text { Rema }\end{array}$ & lal & $\begin{array}{l}\text { value fron } \\
=t_{95.5} \frac{S}{n} \\
\text { es were ol } \\
\text { solution }\end{array}$ & $\begin{array}{l}\text { six different } \\
=6 . \\
\text { ained from } 2\end{array}$ & $\begin{array}{l}\text { ay samples. } \\
\text { onsecutive me }\end{array}$ & rements of \\
\hline
\end{tabular}

\section{Selection of Analytical Lines}

The most prominent lines of the elements being considered were checked, $8-12$ until lines were found that had no interferences. The number of lines examined for each element was different as it depended on the spectral interferences that were seen. The lines that were examined are shown in Table 1.

To demonstrate the absence of significant spectral interferences, scans were taken using the same operating conditions employed to measure assay samples. The solutions used for the scans were: A, near equivalent background concentration
(BEC) of each assay element; B, maximum expected concentration levels of the other elements normally present in the assay solutions and 50 p.p.m. of $\mathrm{Y}$; and C, blank, containing a similar acid concentration to that of the assay solution. Figs. $2-11$ show the results of spectral interference studies that were made. As a result of the complexity of the spectra because of the interfering lines, it is very difficult to differentiate these three solutions in the graphics; for this reason $\mathrm{A}, \mathrm{B}$ and $\mathrm{C}$ are only indicated on the selected interference free lines.

\section{Results}

The wavelengths that were selected for use in the proposed method were: Co, 228.616; Cr, 206.149; Ni, 352.454; W, 207.911; Fe, 259.940; Ta, 228.916; Nb, 316.340; Al, 396.152; $\mathrm{Mo}, 202.030$; and $\mathrm{Mn}, 257.610 \mathrm{~nm}$.

The sample preparation procedure used provided quantitative dissolution of the sample and the corresponding test solution $(0.025 \mathrm{~g}$ of sample plus $5 \mu \mathrm{g}$ of yttrium per $100 \mathrm{ml})$ does not disturb the saline concentration required for the nebulisation.

The operating conditions used provided a good signal to background ratio $\left(I / I_{\mathrm{b}}\right)$ and low background values at the concentration levels being considered.

On account of the linear response of the ICP technique, calibrations were based on two solutions, at similar acid concentrations to the assay sample, containing 50 p.p.m. of yttrium and amounts of each element being considered equivalent to the minimum and the maximum concentrations normally present in Co-base superalloys. Measurements were taken employing yttrium $(\lambda=371.030 \mathrm{~nm})$ as the internal standard

The developed method was tested at each stage of the analytical technique: firstly, by means of synthetic samples prepared by mixing, in suitable proportions, the respective pure powdered metals and finally with standard reference materials from MBH. Results are presented in Table 2. This table shows that the developed ICP-AES procedure can be successfully applied to the analysis of Co-base superalloys.

\section{References}

1. Sims, C. T., and Hagel, W. C., Editors, "The Superalloys," Interscience, New York, 1972.

2. "Metals Handbook," Ninth Edition, Volume 3, American Society for Metals, Metals Park, OH, 1980, p. 257.

3. "Superalloys Source Book," American Society for Metals, Metals Park, OH, 1984

4. Myers, S. A., and Tracy, D. H., Spectrochim. Acta, Part B, $1983, \mathbf{3 8}, 1227$.

5. Wallace, G. F., At. Spectrosc., 1984, 5, 5.

6. "Standard Methods of Analysis," The United Steel Companies, Sheffield 1961

7. Gómez Coedo, A., Dorada López, M. T., and Vindel Maeso, A., Spectrochim. Acta, Part B, 1986, 41, 193.

8. Boumans, P. W. J. M., ICP Inf. Newsl., 1975, 1, 68.

9. Gómez Coedo, A., and Dorado López, M. T., Rev. Metal. (Madrid) , 1980, 16, 159

10. Michaud, E., and Mermet, J. M., Spectrochim. Acta, Part B $1982,37,145$.

11. Winge, R. K., and Fassel, V. A., ICP Inf. Newsl, 1984, 10, 444.

12. Boumans, P. W. J. M., "Line Coincidence Tables for Inductively Coupled Plasma Atomic Emission Spectrometry," Pergamon Press, Oxford, 1984. 